ISSN: 2224-0616

Int. J . Agril. Res. Innov. \& Tech. 7 (2): 18-21, December, 2017 Available online at http://www.ijarit.webs.com

\title{
EFFECT OF VARIETIES AND GROWING ENVIRONMENTS ON TUBER YIELD, NUTRITIONAL AND PROCESS QUALITY OF POTATO GROWN IN BALE HIGHLANDS, SOUTH EASTERN ETHIOPIA
}

\author{
Shure Soboka1, Getachew Asefa'* and Mohammed Beriso ${ }^{2}$ \\ Received 6 July 2017, Revised 26 September 2017, Accepted 24 December 2017, Published online 31 December 2017
}

\begin{abstract}
The highland of Bale is known with potato production, but post harvest quality of the crop is not emphasized yet. Therefore, this study was conducted to evaluate six potato varieties with the objective of assessing the effect of varieties and growing on tuber nutritional and process quality of potato grown in Sinana and Dinsho highlands of Bale. The experiment was laid out in randomized complete block design with three replications. The varieties showed highly significant $(\mathrm{P} \leq 0.05)$ differences for all the parameters studied across the locations. The highest specific gravity, dry matter content and starch content $(1.107,26.61$ and 19.19) were recorded from Dinsho location for Guddene variety while the lowest specific gravity, dry matter content and starch content (1.084, 19.41 and 14.61) were recorded from Sinana location for Ararsa variety. Most of the varieties were recorded as the highest values of specific gravity, dry matter and starch content at Dinsho indicating that it is an ideal location for potato production to be used for processing while Sinana is suitable for the production for home consumption. However, it is necessary to evaluate these varieties for a number of seasons and locations to recommend with high post harvest quality parameters required by the processors.
\end{abstract}

Keywords: Potato, Specific Gravity, Dry Matter and Starch Content

${ }^{1}$ Oromia Agricultural Research Institute, Finfinne, Ethiopia.

${ }^{2}$ Oromia Agricultural Research Institute, Sinana Agricultural Research Center; P.O. Box: 208, Bale-Robe, Ethiopia.

*Corresponding author's email: getachewas@yahoo.com (Getachew Asefa)

\section{Introduction}

The history of potato is the testimony of the fact that whenever, there has been scarcity of food grains, potato has become the food security of people. Potato, because of its great utility, occupies a pre-eminent place amongst the crops and acknowledges as the "King of vegetables" (Barik et al., 2009). More than a billion people eat potatoes, and the total global potato production exceeds 374 million metric tons per year (Devaux et al., 2014). Potato has been highly recommended by the Food and Agriculture Organization (FAO) as a food security crop. It is the third most important food crop in the world after rice and wheat in terms of human consumption (FAO, 2014).

The development of potato varieties with improved post harvest quality and a wide adaptability is important to all segments of potato industry. Processors and other users of potatoes would benefit from a uniform product if varieties produce the same specific gravity when grown in differing environments (Kabira and Berga, 2003). Consumption of potato chips is not common in the country except in the big hotels and restaurants. Recently, small scale potato chips processors are flourishing in cities and big towns. In developing the varieties, much emphasis was given to productivity per unit area and late blight reaction (Asefa et al., 2016) while less emphasis was given to processing quality and studies regarding effect of storage on process and nutritional quality are less probable to get in the country. To meet the demand for varieties suitable for processing industry and storable for longer periods and to keep market with minimum weight and nutritional loss is a very important to evaluate the fitness of the released varieties for processing and to incorporate processing quality as a yardstick in varietal development procedure. Hence, this study was initiated with objectives to study the effect of environments and varieties on nutritional and process quality of potato.

\section{Materials and Methods}

This experiment was conducted in Southeastern Ethiopia, Bale Zone, at Sinana Agricultural Research Center and Dinsho during "Gena" cropping season of 2016. The areas possess a bimodal rainfall type. This bimodal rainfall system has created favorable condition to produce crops twice annually or double crop production season. Average annual maximum and minimum temperatures are 21 and $9{ }^{\circ} \mathrm{C}$, respectively. The dominant soil type is pellic vertisol and slightly acidic (Kedir et al., 2008). 
Hundee, Ararsa, and Milki were released from Sinana Agricultural Research center while Gudenne and Jalene were released from Holleta Agricultural Research Center and Durame was from southern part of Ethiopia were used for the study. The tubers were planted at each location in a Randomized Complete Block Design (RCBD) with three replications. Well-sprouted tubers of each variety were planted in six rows and ten hills per row at spacing of $75 \mathrm{~cm}$ and $30 \mathrm{~cm}$ between rows and plants, respectively. The gross plot size was $4.5 \mathrm{~m} \mathrm{x} 3.0 \mathrm{~m}$, and the distance between blocks and plots was $1.5 \mathrm{~m}$ and $1.0 \mathrm{~m}$, respectively. Fertilizer application was made as per the national recommendation made for the crop which is $92 \mathrm{~kg} \mathrm{P}_{2} \mathrm{O}_{5}$ ha- $^{-1}$ in the form of Diammonium Phosphate (200 kg ha-1) and the whole rate was applied at planting. Nitrogen fertilizer was applied at the rate of $75 \mathrm{~kg} \mathrm{ha}^{-1}$ in the form of Urea in two splits, half rate after full emergence (two weeks after planting) and half rate at the initiation of tubers (at the start of flowering). Moreover, other agronomic managements rather than varietal differences, like weeding, earthining up, were uniformly applied to all experimental plots.

\section{Data collection}

Specific gravity of tubers (Sg): This was determined by the weight in air and in water method. Five kilograms of tubers of all shapes and sizes were randomly taken from each plot. The tubers were washed with water. Then after the sample was first weighed in air and then reweighed suspended in water. Specific gravity was calculated according to Kleinkopf et al. (1987) formula.

Specific gravity $=\frac{\text { Weight in air }}{\text { Weightin air-Weight in Water }}$

To convert specific gravity value to dry mater and starch content, the equation from Kleinkopf et al. (1987) of dry matter $(\%)=-214.9206+218.1852$ $\times$ (specific gravity) and Von Schéele et al. (1937) of starch $(\%)=17.565+199.07 \times($ specific gravity) - 1.0988) were used.

Total tuber yield (TTY) (t ha-1): This was determined as the sum of the weights of marketable and unmarketable tubers from the net plot area and converted to tons per hectare

\section{Data analysis}

Collected data was subjected to analysis of variance (ANOVA) for RCBD using Genstat 15th edition computer software. Means that are significantly different were compared using Least Significant Difference (LSD) of probability at 5\% level of significance.

\section{Results and Discussion}

Analysis of variance indicated the presence of significant $(\mathrm{P} \leq 0.05)$ differences among varieties for specific gravity. The specific gravity (SG) was influenced by location. Accordingly, the specific gravity of tubers grown at Dinsho was higher than that of corresponding varieties grown at Sinana except milki (Table 1). The highest SG value (1.107 and 1.106) in Dinsho was recorded from the improved variety of Gudanne and Jallene, respectively while the highest SG value at Sinana was recorded from Milki variety. Contrary, the lowest specific gravity (1.094 and 1.086) was obtained from Ararsa at Dinsho and Sinana, respectively. This is in line with Tesfaye et al. (2010) who indicated the difference of specific gravity of potato varieties within three distinct environments ranged from 1.119 to 1.050 for improved varieties of Belete and Menagesha. High specific gravity is an indication that the raw potatoes will produce high chips volume due to high dry matter content of tubers. Fitzpatrick et al. (1964) categorized tuber specific gravity values as low if less than 1.077, intermediate if between 1.077 and 1.086 and high if more than 1.086 . Accordingly, all released varieties under the two locations, except Ararsa at Sinana, of the study were categorized under high specific gravity indicating that they are fit for processing.

Table 1. Mean of specific gravity, dry matter, starch content and total tuber yield of six potato varieties evaluated under two environments in Bale high lands.

\begin{tabular}{llcccc}
\hline Locations & Varieties & $\begin{array}{c}\text { Specific } \\
\text { gravity }\left(\mathrm{g} \mathrm{cm}^{-3}\right)\end{array}$ & $\begin{array}{c}\text { Dry mater } \\
\text { content }(\%)\end{array}$ & $\begin{array}{c}\text { Starch content } \\
(\%)\end{array}$ & $\begin{array}{c}\text { Total Tuber } \\
\text { Yield(ton ha- }\end{array}$ \\
\hline \multirow{6}{*}{ Dinsho }
\end{tabular}

$\mathrm{CV}=$ coefficient of variation, $\mathrm{LSD}=$ least significant different. 
Dry matter content of tuber was significantly $(p<0.05)$ influenced by varieties and growing environment. The mean dry matter content ranged between 26.61 to 23.77 and 26.39 to 19.41 at Dinsho and Sinana, respectively. At both locations, the lowest dry matter content was recorded from the improved variety called Ararsa. But, the varieties containing the highest dry matter content differed across the sites. The maximum dry matter content was recorded from Gudanne and Jalanne at Dinsho while the maximum dry matter content was recorded for Milki at Sinana. The difference of dry matter content at both locations may be due to

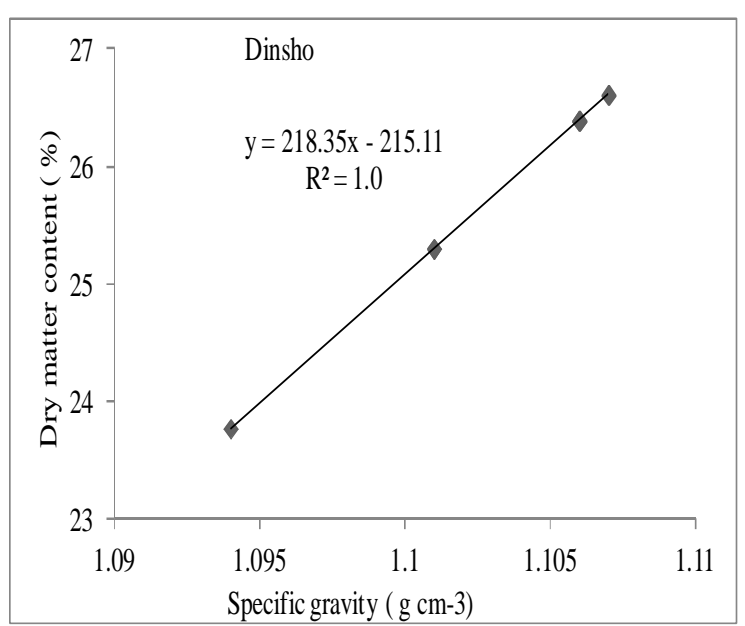

environmental factors contributing to this crop quality parameter. Many attempts have been reported to correlate variations found in specific gravity of tubers with cultural practices and environmental conditions. The result of correlation analysis revealed that more dry matter accumulation was observed in Dinsho as the function of increasing specific gravity than at Sinana (Fig. 1). Tesfaye et al. (2010) and Elfnesh et al. (2011) also reported that different dry matter content were observed within the same varieties at different locations.

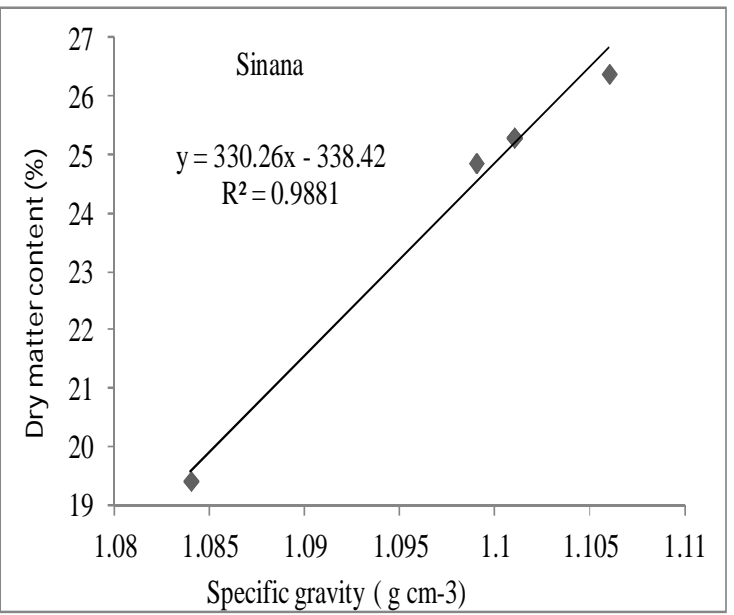

Fig. 1. The relation of specific gravity to dry matter content for sex varieties of Potatoes at Dinsho and Sinana areas of Bale highland.

Like dry matter content and specific gravity, starch content of the varieties was also different with different locations. The highest starch content was obtained from Gudanne (19.19\%) and J alanne (18.99\%) at Dinsho while the highest (18.99\%) at Sinana was recorded from Milki variety. However, the lowest starch content from Ararsa variety was $16.6 \%$ and $14.61 \%$ at Dinsho and Sinana, respectively. The result from study revealed that, for both locations there were significant difference for tuber dry matter content, starch content and specific gravity indicating that the varieties showed a differential response to the characters in the different environments. Similar findings were reported previously by Kabira and Berga (2003), Tesfaye et al. (2010), Abebe et al. (2012) and Tsegaw, (2015).

\section{Conclusion}

The study confirmed that there were existences of considerable variations among the varieties in terms of specific gravity, dry matter and starch contents indifferent environments. This indicated us quality characters of potato are governed by both varieties and environments. Most of the varieties under the study were recorded as the highest values of specific gravity, dry matter and starch content at Dinsho indicating that it is an ideal location for production of potato to be used for processing while Sinana is suitable to produce for table type potato production. However, it is hardly possible to make conclusion with two locations experiment. Therefore, it is necessary to evaluate these varieties for a number of seasons and locations to recommend the varieties with good and acceptable processing quality parameters.

\section{Acknowledgement}

The authors are grateful to Oromia Agricultural Research Institute, AGP II donors and Sinana Agricultural Research center for the financial support and facilitation of vehicle for this research work. 


\section{References}

Abebe, T., Shermarl, W., Thunya, T. and Oranuch, L. 2012. Dry Matter Content, Starch Content and Starch Yield Variability and Stability of Potato Varieties in Amhara Region of Ethiopia. Kasetsart J. (Nat. Sci.) 46: $671-683$.

Asefa,G., Mohammed, W. and Abebe, T. 2016. Evaluation of potato genotypes for resistance to late blight southeastern Ethiopia. Int. J. Agril. Res. Innov. \& Tech. 6(1): 21-25.

Barik, S.B., Verma, S.K. Nanda, H.C. and Tamrakar, S.K. 2009. Genetic variability, heritability and genetic advance for yield and its attributes in potato (Solanum tuberosum L.) Indira Gandhi Krishi Vishwavidyalaya Ann. Agril. Res. New Series 30(1\&2): 39-42.

Devaux, A., Kromann, P. and Ortiz, O. 2014. Potatoes for Sustainable Global Food Security. Potato Res. 57 (3-4): 185-199.

Elfnesh, F., Tekalign, T. and Solomon W. 2011. Processing quality of improved potato (Solanum tuberosum L.) cultivars as influenced by growing environment and blanching. African J. Food Sci. 5(6): 324332.

FAO. 2014. FAO statistical databases FAOSTAT Food and Agriculture Organization, Rome, Italy. http:// faostat3.fao.org/ Accessed 8 Jun 2014.

Fitzpatrick, J.J., Porter, W.L. and Houghland, V.C. 1964. Continued studies of the relationship of specific gravity to total solids of potato. American Potato J. 46: 120-127.
Kabira, J. and Berga, L. 2003. Potato processing quality evaluation procedure for research and food industry applications in east and central Africa. Kenya Agricultural Research Institute, Nairobi, Kenya, p. 39.

Kedir, N., Tilahun, G. and Allo, A. (ed.) 2008. Fifteen years achievement: Oromia Agricultural Research Institute, Sinana Agricultural Research Center, Bale-Robe, Southeast Ethiopia, p. 53.

Kleinkopf, G.E., Westermann, D.T., Wille, M.J. and Kleinschmidt, G.D. 1987. Specific gravity of Russet Burbank potatoes. American Potato J . 64: 579- 587.

Tesfaye A., Lemaga, B., Mwakasendo, J.A., Nzohabonayoz, Z., Mutware, J., Wanda, K.Y., Kinyae, P.M., Ortiz, O., Crissman, C. and Thiele, G. 2010. Markets for Fresh and Frozen Potato Chips in the ASARECA Region and the Potential for Regional Trade: Ethiopia, Tanzania, Rwanda, Kenya, Burundi and Uganda. Working Paper. International Potato Center (CIP). Lima, Peru, $44 \mathrm{p}$.

Tsegaw, T. 2015. Genotype x Environment Interaction for Tuber Yield, Dry Matter Content and Specific Gravity in Elite Tetraploid Potato (Solanum tuberosum L.) Genotypes . East African J. Sci. 5(1): 1-5.

Von Scheele, C., Svensson, G. and Rasmusson, J. 1937. Determination of the starch content and dry matter of potatoes with the aid of specific gravity. [in German] Land wirtsch. Vers. Sta. 127: 67-96. 